\title{
Bacteria and heterotrophic flagellates in the pelagic carbon cycle in the northern Baltic Sea
}

\author{
Harri Kuosa, Kai Kivi \\ Tvärminne Zoological Station, SF-10900 Hanko, Finland
}

\begin{abstract}
The annual course of phytoplankton and bacterial productivity and the carbon requirement of heterotrophic flagellates were studied in the Tvärminne area, northern Baltic Sea, during 1986. Phytoplankton productivity had a strong spring maximum, which was followed by a bacterial productivity peak formed by cold-adapted bacteria. In summer bacterial productivity was positively correlated with water temperature. Annual bacterial productivity was $15 \%$ of net primary productivity. According to our calculations algal exudation could fulfil 50 to $65 \%$ of the annual bacterial carbon requirement. Bacterial production could satisfy only about half to the flagellate carbon requirement. This suggests that in order to meet their carbon requirement, heterotrophic flagellates also have to graze on small algae. Of the total net primary production, about $35 \%$ was utilized directly by bacteria or heterotrophic flagellates. This emphasizes the importance of heterotrophic microbes in the pelagic carbon cycle of the northern Baltic Sea.
\end{abstract}

\section{INTRODUCTION}

Bacteria are considered to be an important part of the pelagic carbon cycle (Williams 1981, Azam et al. 1983). Recent studies have shown that heterotrophic nanoflagellates function as major grazers of bacteria in many oceanic ecosystems (Haas \& Webb 1979, Fenchel 1982, 1986, Linley et al. 1983, Landry et al. 1984, Andersen \& Fenchel 1985, Joint \& Williams 1985, Rivier et al. 1985, Andersen \& Sørensen 1986, Rassoulzadegan \& Sheldon 1986). Phagotrophic protozoa form a link to metazoa (Sherr et al. 1986a).

The role of pelagic bacteria in the northern Baltic Sea has been evaluated by Larsson \& Hagström (1979, 1982), Kuparinen (1984) and Virtanen (1985). They have shown that bacteria produce a considerable amount of carbon (at least $10 \%$ ) compared with primary production. Larsson \& Hagström (1982) have shown that a substantial part of the bacterial carbon requirement comes from algal exudation (cf. also Kuparinen 1987). The fate of bacterial production is not yet fully clear and the role of heterotrophic flagellates in the northern Baltic is poorly known. Gast (1985) has shown the importance of bacteria as a food source for microzooplankton (including flagellates) in the southern Baltic Sea. Rheinheimer (1984) stressed the important role of bacteria and protozoa in the Kiel Bight ecosystem.
This study describes the pattern of primary and bacterial productivity at a fixed station in the northern Baltic Sea in 1986. The carbon requirement of heterotrophic flagellates was also estimated. The factors causing variability in bacterial productivity are examined.

\section{INVESTIGATION AREA}

Samples were taken at a station off Tvärminne Långskär in the Gulf of Finland $\left(59^{\circ} 50^{\prime} \mathrm{N}, 23^{\circ} 10^{\prime}\right.$ E). Water depth at the station is $40 \mathrm{~m}$. The thermocline, which during the summer can be found between 10 and $15 \mathrm{~m}$, is frequently broken by upwellings, which bring cold, nutrient-rich water to the surface (Niemi 1973, Hällfors et al. 1983). The mean salinity is about $6 \%$.

The seasonal nutrient and zooplankton dynamics in the study area are well known (Niemi 1973, 1975, Forsskåhl \& Sundberg 1981, Hällfors et al. 1983, Kuparinen et al. 1984). A general outline of the phytoplankton succession has been presented by Niemi (1975) and the following description is largely according to him. The phytoplankton shows a pronounced spring maximum after the break up of the ice, chlorophyll a values reaching a maximum of $40 \mu \mathrm{g} \mathrm{l} \mathrm{l}^{-1}$. In summer, chlorophyll a concentrations vary between 1 and $2 \mu \mathrm{g} \mathrm{l}^{-1}$, showing, however, a late summer peak ( 3 to $7 \mu \mathrm{g} \mathrm{l}^{-1}$ ) during the time of the blue-green algal 
maximum. In autumn and winter chlorophyll a concentrations are generally below $1 \mu \mathrm{g} \mathrm{l}^{-1}$. Annual phytoplankton production (apparent net) is near $100 \mathrm{~g} \mathrm{C} \mathrm{m}^{-2}$ (Kuparinen 1984). The average bacterial number is about $1.5 \times 10^{6} \mathrm{ml}^{-1}$, their biomass about $5 \mathrm{mg} \mathrm{C} \mathrm{m}^{-3}$ (Virtanen 1985, cf. Väätänen 1980a), and annual bacterial production is estimated to be 10 to $20 \mathrm{~g} \mathrm{C} \mathrm{m}^{-2}$ (Kuparinen 1984). According to Väätänen (1980b), the study area has conditions similar to those in the open Baltic and can suitably be used for microbiological monitoring. As regards the numbers and biomass of heterotrophic nanoflagellates in the study area, no previous data are available.

In 1986 hydrographical conditions followed a pattern typical for the study area (Fig. 1). Ice-cover remained until mid-April. The water began to warm up at the beginning of May and between May and August it was more or less stratified, with a thermocline between 10 and $15 \mathrm{~m}$. As often occurs here, upwellings disturbed the water stratification several times during the summer, the most important taking place in July and August (Fig. 1). At the end of August a degeneration of the thermocline occurred similar to that described by Smetacek et al. (1984) from the Kiel Bight. The result of this was a warming of the lower water strata. After the degeneration of the thermocline the whole water mass gradually cooled toward winter temperatures.

\section{MATERIALS AND METHODS}

The study was undertaken between 4 February and 17 December 1986. Samples were taken with a Ruttner-type water sampler (2.5 l) from 3 depths. The surface sample was taken as a combined sample from 0 to $5 \mathrm{~m}$ (samples from $0.5,1.5,2.5,3.5$ and $4.5 \mathrm{~m}$ ). The 10 and $20 \mathrm{~m}$ samples were both collected as 3 separate samples, which were combined before two 11 sub- samples were taken. Sampling was performed between 09:30 and 10:30 h. Water temperature was measured at 10 depths. During the period of ice-cover, samples were taken from 0,1 and $15 \mathrm{~m}$. Samples were taken twice a week during the spring and summer and once a week during the rest of the year. Total number of samplings was 60 .

Bacterial production was measured from the uptake of tritiated thymidine (Fuhrman \& Azam 1980, 1982). [Methyl- ${ }^{3} \mathrm{H}$ ]thymidine was added at a final concentration of $10 \mathrm{nmol}$ (specific activity 40 to $54 \mathrm{Ci} \mathrm{mmol}^{-1}$ ), which is more than the rate-saturating concentration in the study area (Bell 1986). All radioactive solutions used in this study were provided by Amersham International Ltd, UK. Two $20 \mathrm{ml}$ samples and a formalinkilled adsorption control from each sampling depth were incubated at in situ temperature for 2 to $4 \mathrm{~h}$. The incubations were stopped with formalin (final conc. 0.5 $\%$ ). The samples were kept at $+4{ }^{\circ} \mathrm{C}$ before extraction, which was performed at most $1 \mathrm{wk}$ after sampling. The thymidine samples were extracted with ice-cold TCA according to Fuhrman \& Azam $(1980,1982)$. The TCAinsoluble fraction was collected by filtering the sample through a $25 \mathrm{~mm} 0.2 \mu \mathrm{m}$ pore-size Sartorius filter. The percentage of thymidine converted to protein was not checked.

Bacterial production was calculated using the conversion factor $1.1 \times 10^{9}$ cells nmol $^{-1}$ (Riemann et al. 1987), mean cell volume $0.045 \mu^{3}$ and mean carbon content $0.27 \mathrm{pg} \mu^{3}$ bacterial biovolume (Kuparinen unpubl.). Bacterial productivity per $\mathrm{m}^{2}$ was calculated using the mean value of the 0 to 5 and $10 \mathrm{~m}$ samples for the surface water layer ( 0 to $15 \mathrm{~m}$; in summer usually coinciding with the layer above the thermocline) and the $20 \mathrm{~m}$ value for the 15 to $40 \mathrm{~m}$ water layer. The surface $(0$ to $5 \mathrm{~m}$ ) and $10 \mathrm{~m}$ samples never differed much from each other $(r=0.96)$.

Primary production was measured by the ${ }^{14} \mathrm{C}$ method (Steemann Nielsen 1952) by adding $5 \mu \mathrm{Ci} \mathrm{NaH}{ }^{14} \mathrm{CO}_{3}$ to

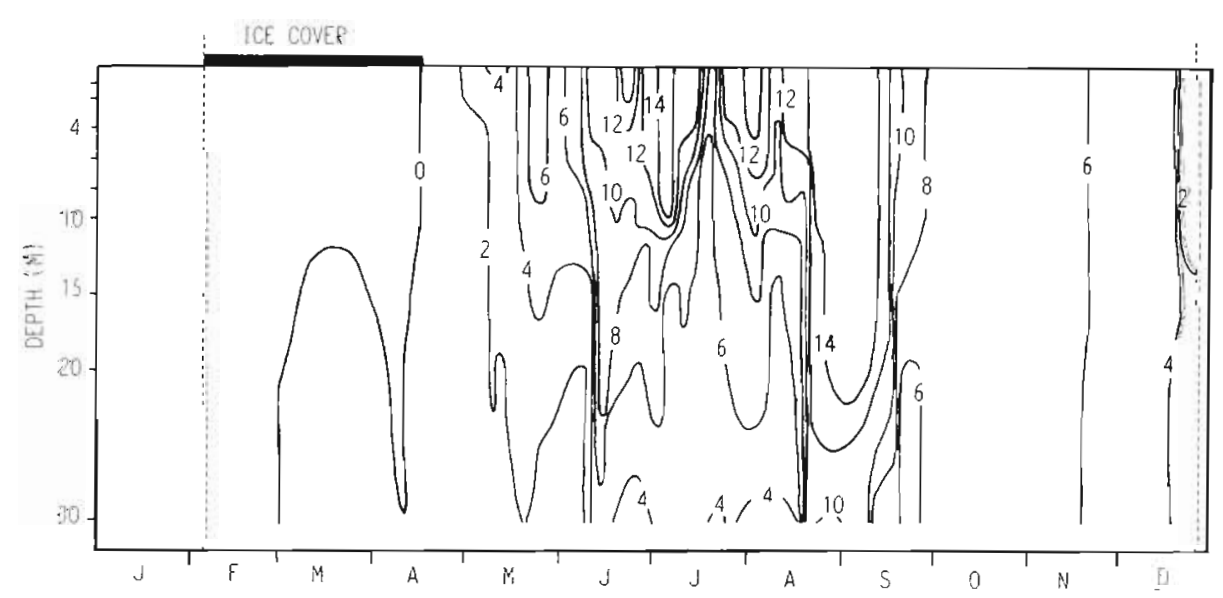

Fig. 1. Water temperature $\left({ }^{\circ} \mathrm{C}\right)$ in 1986 at the station off Tvärminne, northern Baltic Sea. Ice-cover period is indicated by a black bar. Broken lines indicate starting and ending dates of the study. Only sampling depths have been marked on the $y$-axis. Due to the high frequency of samplings, they have not been indicated in the figure 
$100 \mathrm{ml}$ water samples from the surface layer $(0$ to $5 \mathrm{~m})$ The samples were incubated in glass bottles in situ for $24 \mathrm{~h}$ at the following depths: $0.2,2$ and $5 \mathrm{~m}, 2$ light and 1 dark bottle at each depth. Under ice-cover incubation depths were $0.2,1$ and $5 \mathrm{~m}$, using $20 \mathrm{ml}$ glass bottles $\left(1 \mu \mathrm{Ci} \mathrm{NaH}{ }^{14} \mathrm{CO}_{3}\right)$. Apparent net primary production was measured from $4 \mathrm{ml}$ subsamples according to Niemi et al. (1983), For radioactivity measurements ( ${ }^{3} \mathrm{H}$ and ${ }^{14} \mathrm{C}$ ) PCS liquid scintillation cocktail (Amersham) and a Wallac 1219 RackBeta liquid scintillation counter (LKB-Wallac Co., Finland) were used. A primary production curve was produced by linear interpolation between production values from different depths. Primary productivity per $\mathrm{m}^{2}$ was calculated from this graph. The surface $(0.2 \mathrm{~m})$ incubation was intended to reveal the amount of surface inhibition and the $2 \mathrm{~m}$ incubation was designed to coincide with the depth of maximum production. In fact, surface inhibition was never observed. The compensation depth, which was rarely more than $15 \mathrm{~m}$, was defined as $2 \times$ Secchi depth (Niemi 1975).

Heterotrophic flagellates were enumerated with a Leitz Dialux epifluorescence microscope using the proflavine staining technique (Haas 1982). The microscope was fitted with a HBO-50 mercury lamp. A $100 x$ oil immersion objective, a 3 mm BG 12 exciting filter, a built-in $2 \times \mathrm{KP} 490$ (= KP 500) interference filter and a K 510 suppression filter were used. The samples were fixed with formalin (final conc. $2 \%$ ). At least 50 cells were enumerated on 1 subsample per depth. The volume taken for a heterotrophic flagellate $\left(16 \mu \mathrm{m}^{3}\right)$ was the average volume calculated from monthly measurements of 50 flagellates. The mean volume of the flagellates varied little between the measured samples (from 11 to $19 \mathrm{um}^{-3}$ ), since the bulk of the flagellates were always small (diameter 3 to $4 \mu \mathrm{m}$ ). The mean flagellate carbon content of $0.22 \mathrm{pg} \mathrm{C} \mathrm{um}^{3}$ biovolume for formalin-fixed cells was used as suggested by Børsheim \& Bratbak (1987). Diel changes in flagellate numbers and bacterial production were not studied.
The carbon requirement of heterotrophic flagellates was calculated in a study (Kuosa \& Marcussen 1988) in which the amount of food grazed by nanoflagellates was evaluated. From these results the mean value of carbon consumed by a flagellate $47.5 \%$ of flagellate $C$ $\mathrm{d}^{-1}$ ) could be obtained and was used in our calculations. The flagellate carbon requirement per $\mathrm{m}^{2}$ was calculated analogously to the bacterial productivity. As discussed in Kuosa \& Marcussen (1988), the figure obtained for the nanoflagellate carbon requirement is near to the minimum energy requirement of starving flagellate cells (Fenchel 1982). It is felt that by using this figure we do not grossly overestimate the flagellate carbon requirement. The low carbon consumption by flagellates leads to a low growth rate of flagellates. If flagellate growth efficiency is $50 \%$, the mean generation time would be about $4 \mathrm{~d}$, which, according to our later studies in the northern Baltic (Kuuppo-Leinikki \& Kuosa unpubl.) is not unrealistically low.

\section{RESULTS}

\section{Subperiods}

The study period was divided into subperiods according mainly to the observed variation in water temperature stratification. The hydrographical observations were supplemented with primary productivity data. The winter period (4 Feb to 2 Apr) was characterized by ice-over, low water temperatures and low primary productivity. The spring period (2 Apr to 2 Jun) was defined as the period between the start and end of the spring primary productivity peak(s). The spring bloom started under ice-cover. The end of the spring bloom was somewhat difficult to define, due to several minor primary productivity peaks after the productivity maximum (Fig. 2). The summer period (2 Jun to 4 Sep) was mostly characterized by a clear temperature stratification. The starting point of the autumn period $(4$
Fig. 2. Primary productivity per $\mathrm{m}^{2}$ in the Tvärminne sea area in 1986

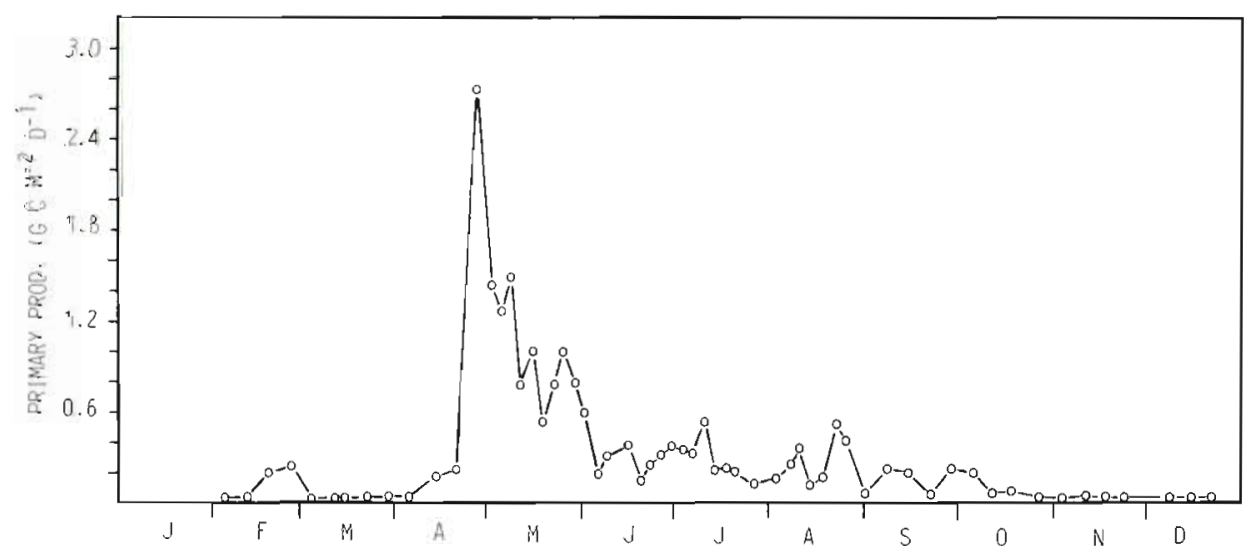


Table 1 Carbon flow estimates for primary production, bacterial production and flagellate carbon demand in 1986 in the Tvärminne sea area

\begin{tabular}{|lccccc|}
\hline Period & No. of days & $\begin{array}{c}\text { Prim. prod. } \\
(\mathrm{g} \mathrm{C} \mathrm{m})\end{array}$ & $\begin{array}{c}\text { Bact. prod. } \\
\left(\mathrm{g} \mathrm{C} \mathrm{m}^{-2}\right)\end{array}$ & $\begin{array}{c}\text { Bact./prim. } \\
\text { prod. }(\%)\end{array}$ & $\begin{array}{c}\text { Flag. demand } \\
\left(\mathrm{g} \mathrm{C} \mathrm{m} \mathrm{m}^{-2}\right)\end{array}$ \\
\hline Winter & 59 & 3.23 & 0.45 & 13.9 & 0.97 \\
Spring & 62 & 47.82 & 5.58 & 11.7 & 6.66 \\
Summer & 86 & 22.55 & 5.05 & 22.4 & 8.92 \\
Autumn & 110 & 8.56 & 1.41 & 16.5 & 6.41 \\
Total (mean) & 317 & 82.16 & 12.49 & $(15.2)$ & 22.96 \\
\hline
\end{tabular}

Sept to $17 \mathrm{Dec})$ was taken as the time of the complete degeneration of the thermocline. All values (primary and bacterial productivity and flagellate carbon requirement) for the subperiods were calculated by multiplying the average value per $\mathrm{m}^{2}$ for a subperiod by the number of days of that subperiod.

\section{Primary productivity}

The primary productivity data show the great relative importance of the spring bloom (Fig. 2; Table 1): $60 \%$ of the total primary production took place during $20 \%$ of the study period. This is in accordance with previous studies (e.g. Niemi 1975, Kuparinen 1984, 1987), though the absence of a late summer productivity maximum lowered the relative importance of the summer period in 1986. During the late summer maximum, the phytoplankton consists of blue-green algae (Niemi 1973), which in 1986 suffered from an unusually low water temperature in July-August. The relative importance of the winter period was modest although a low productivity peak was observed under thin ice in February (Fig. 2). During the long autumn period the primary productivity was low (Table 1 ).

\section{Bacterial productivity and carbon requirement of heterotrophic flagellates}

Bacterial productivity had a major peak soon after the high primary productivity peak in spring (Fig. 3). This kind of bacterial dynamics has been shown in the northern Baltic by the carbon uptake results of Larsson \& Hagström (1979), the bacterial biomasses of Kuparinen et al. (1984) and the heterotrophic potential values of Virtanen (1985) and Kuparinen (1987). The bacterial productivity maximum at a low water temperature ( 2 to $6{ }^{\circ} \mathrm{C}$ ) shows adaptation of spring bacteria to the cold environment.

In summer, bacterial production dynamics seemed to be closely connected with the hydrography. All the bacterial productivity peaks coincided with the periods of strongest stratification and highest surface water temperature. (Figs. 1 and 3). The connection between bacterial productivity in the surface water layer and surface water temperature in summer and early autumn is also evident from a statistically significant correlation $(p<0.050)$ between these 2 parameters (Fig. 4). Virtanen (1985) also observed a connection between bacterial number and water temperature in summer. A partial correlation test was applied to the

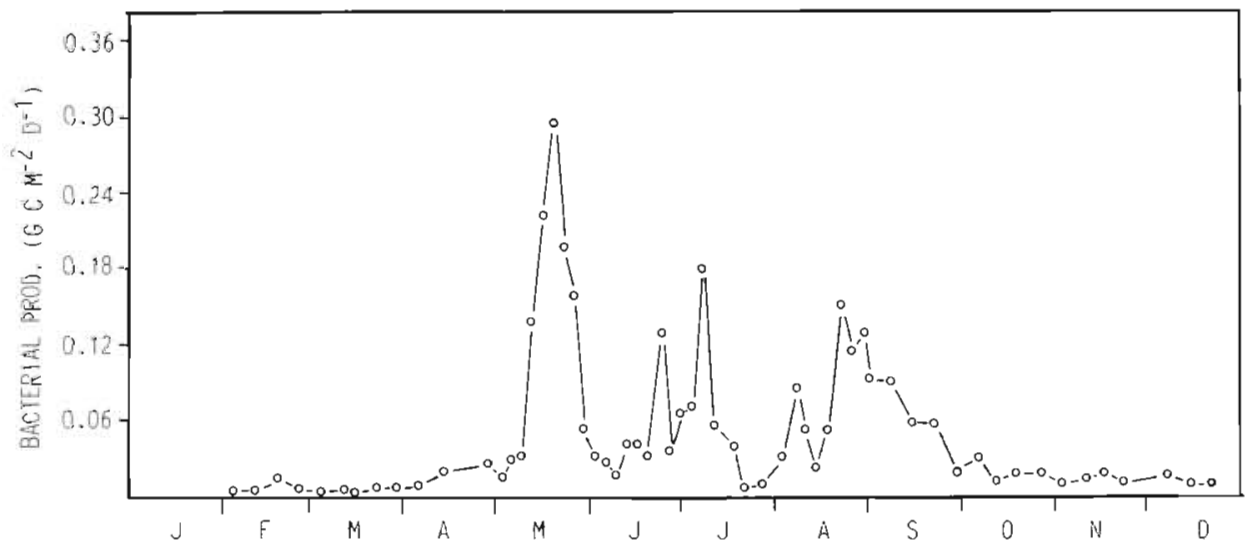

Fiq. 3. Bacterial productivity per $\mathrm{m}^{2}$ in the Tvärminne sea area in 1986 


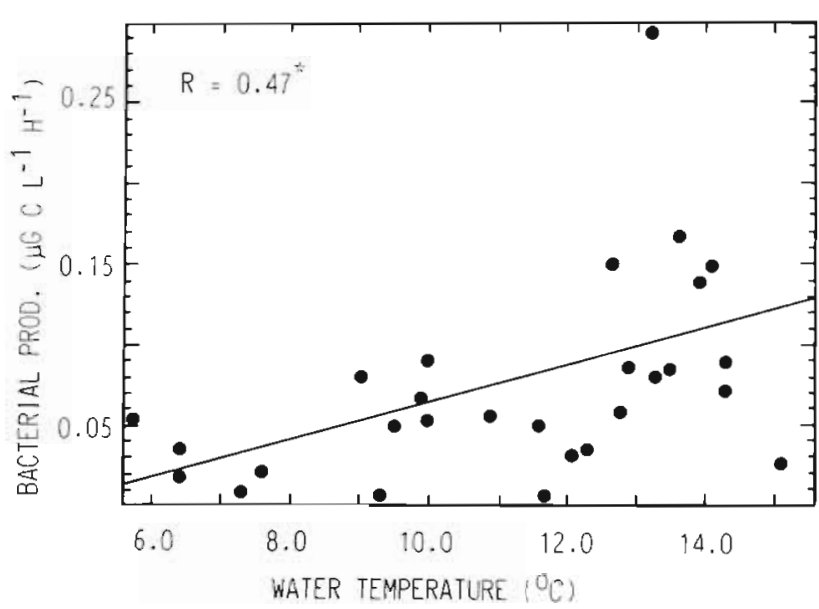

Fig. 4. Correlation between surface water temperature and surface bacterial productivity during summer and early autumn (2 June to 2 Oct 1986). "Statistically significant correlation $(p<0.05)$

summer and early autumn data (surface bacterial productivity:primary productivity:surface water temperature). It showed a relatively high, but not statistically significant, correlation $(p<0.052)$ between bacterial productivity and primary productivity. When a lag of one sampling was applied to the bacterial productivity data in relation to the primary productivity data, the partial correlation coefficient was statistically significant $(p<0.025)$. This may indicate dependence of bacterial productivity on primary productivity, with some time delay in bacterial response to changing primary production. However, another interpretation of our data is that both primary and bacterial productivity were controlled by an unknown factor in summer (e.g. by the cycling time of nutrients). The partial correlation test also revealed a statistically significant $(p<0.050)$ correlation between bacterial productivity and temperature. Primary productivity and temperature were not significantly correlated $(p>0.300)$.

The carbon requirement calculated for heterotrophic flagellates was almost twice the bacterial production (Table 1). However, strong seasonal differences existed. During the summer and especially during the autumn period the carbon requirement of heterotrophic flagellates greatly exceeded bacterial production. This indicates that flagellates satisfy part of their carbon requirement from sources other than bacteria. We know from a previous study made in the Tvärminne area (Huttunen \& Kuparinen 1986) that the production of phytoplankters less than $3 \mu \mathrm{m}$ in size increases during late summer and autumn. As heterotrophic flagellates are known to graze on pico-planktonic and nanoplanktonic algae (e.g. Landry et al. 1984, Marchant 1985 ), a part of their carbon requirement may have been fulfilled by small algae. Goldman \& Caron (1985) and Suttle et al. (1986) have shown that flagellates also ingest larger phytoplankton cells. If the bacterial production was consumed only by flagellates, the mean numbers of bacteria grazed by a flagellate $\left(\mathrm{h}^{-1}\right)$ in the winter, spring, summer and autumn periods would be, respectively, $1.6,4.5,1.9$ and 0.7 .

During the spring period, the carbon requirement of heterotrophic flagellates was almost in balance with the bacterial production. However, the increase in flagellate numbers in spring started before the spring bacterial productivity peak. This can be explained by the occurrence of picoplanktonic algae and small phytoflagellates during the whole spring bloom (Kuosa unpubl.), though the bulk of the bloom consisted of large algae (diatoms and dinoflagellates).

In summer, the first 2 bacterial productivity peaks coincided with a minimum of heterotrophic flagellates (Fig. 5). This can be interpreted in 2 ways. It may be the consequence of a cyclic predator-prey relationship, in which bacterial and flagellate peaks follow each other. It may also be the direct consequence of decreased flagellate grazing on over-grazed bacteria, which leads to a rapid increase of bacterial productivity. The second explanation is more likely in this case, as the bacterial
Fig. 5. Calculated carbon requirement of heterotrophic flagellates per $\mathrm{m}^{2}$ in the Tvärminne sea area in 1986

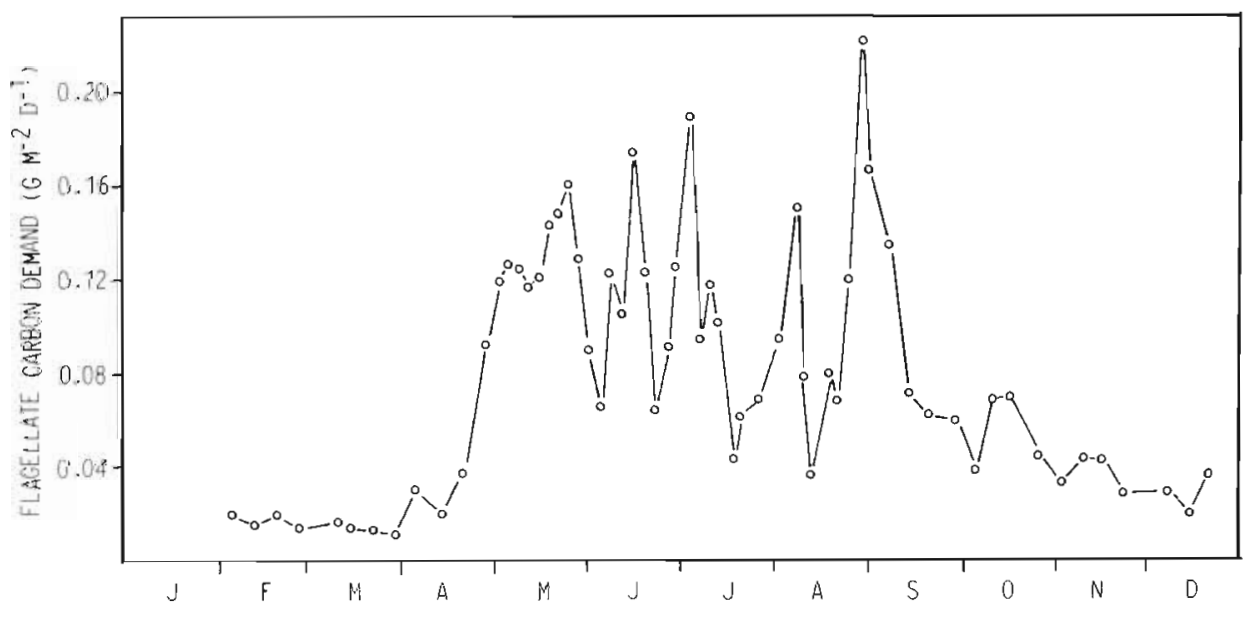


community seems to live under grazing pressure throughout the summer and flagellates do not seem to be totally restricted to bacteria as a food source. The reasons underlying changes in flagellate numbers are still unknown, but ciliate grazing on flagellates is a potential explanation, which should be studied. The third and fourth bacterial productivity peaks coincided with flagellate peaks, showing the recovery of both bacterial and flagellate populations after strong upwellings.

\section{DISCUSSION}

When calculating the results, we became aware of the great lack of information on many crucial points. We had to use values from the literature, some of which related to different areas or different organisms. Thus, much of the following discussion should be considered only speculative until we can obtain more results on phytoplankton exudate release, bacterial growth yield, bacterial carbon production and flagellate carbon requirement, and their diel and annual variation in the northern Baltic.

We did not measure exudate release by phytoplankton during this study, due to the fragility of algae in these waters, which prevents the use of filtration in exudate measurements (Lignell \& Kuosa 1988). Therefore, the importance of exudates as a carbon source for bacteria can be estimated only roughly. If the exudation values (12 to $16 \%$ ) obtained by Larsson \& Hagström (1982) are applied and the growth yield of bacteria is assumed to be $60 \%$ (Hobbie \& Crawford 1969), exudation would fulfil about 50 to $65 \%$ of the annual bacterial carbon requirement. This value is near the value $(50 \%)$ reported by Larsson \& Hagström (1982).

Virtanen (1985) concluded that in spring bacterial numbers were regulated by the availability of organic matter. Senescent algae release dissolved organic matter (DOM) into the water via leakage and autolysis (e.g. Azam \& Ammerman 1984). This new pool of DOM seems to be the main factor underlying the phytoplankton-bacteria dynamics observed in spring.

The largest discrepancy between exudation and bacterial production was found during the summer period, when the calculated bacterial carbon requirement is about $30 \%$ of primary production, i.e. twice the mean exudation. One possible explanation of high bacterial production during summer is sloppy feeding by herbivorous zooplankton (Lampert 1978), which releases dissolved organic matter into the water by fracturing algal cells. The herbivorous zooplankton community has its maximum biomass in summer in the northern Baltic (Kuparinen et al. 1984). Another explanation is the increased algal exudation in summer (over $30 \%$ of phytoplankton production) observed by Kuparinen (1987), which could provide sufficient carbon for bacteria.

The average bacterial carbon requirement was $20 \%$ of primary productivity. This value is at the lower end of the range of estimates (20 to $60 \%$ ) made by Linley et al. (1983) for shelf waters.

The carbon requirement calculated for bacteria is naturally dependent on the growth yield value. If the value $(60 \%)$ used in this study is an overestimate and the value $(20 \%)$ presented by Bjørnsen (1986) is closer to reality, the role of bacteria has to be re-evaluated (cf. also Smith et al. 1986). Studies on the growth yield of natural bacteria will be of major importance in future studies made in the northern Baltic. The conversion factors for bacterial production measurements by the thymidine method also have to be critically reconsidered and studied during the whole annual cycle. Also, we have no idea of the proportion of Baltic bacteria not capable of taking up thymidine (Pollard \& Moriarty 1984)

The ratio of annual bacterial production to net primary production $(15 \%)$ is the same as the value reported by Meyer-Reil (1977), which was measured at a station on the Kiel Bight, where the annual primary productivity ( $60 \mathrm{~g} \mathrm{C} \mathrm{m}^{-2}$ ) was close to that $\left(82 \mathrm{~g} \mathrm{C} \mathrm{m}^{-2}\right.$ ) measured in Tvärminne. Our figure is also within the range of values (9 to $21 \%$ ) reported by Kuparinen (1984), but it is lower than the values (18 and $24 \%$ ) given by Larsson \& Hagström (1982) from the Swedish coast. On the other hand, it is considerably higher than the values reported from the Georges Bank (Sissenwine et al. 1984) and shelf water ecosystems (Linley et al. 1983) ( $8 \%$ and 5 to $8 \%$, respectively).

One possible source of error in our estimations is the evaluation of the carbon requirement of heterotrophic flagellates. The value used throughout the year is based on only one experiment. This part of the calcula. tions may need revision after we have obtained more information on the seasonal variation of carbon consumption by heterotrophic flagellates. The role of chloroplast-bearing mixotrophic flagellates also has to be evaluated (Bird \& Kalff 1986, 1987, Estep et al. 1986). One question that is still open is the importance of ciliate grazing on bacteria in the northern Baltic (Sherr \& Sherr 1987).

The direct consumption of primary production by heterotrophic flagellates was calculated to be $13 \%$. This figure is based on the assumption that all bacterial production is consumed by heterotrophic flagellates, and that the extra carbon required is obtained by grazing on primary producers. According to Joint \& Williams (1985), bacterial production was not sufficient to fulfil the carbon requirement of the heterotrophic flagellate community in the Celtic Sea. Linley et al. 
(1983) concluded in their study that at least $66 \%$ of bacterial production is consumed by heterotrophic flagellates. All these figures show the importance of heterotrophic flagellates as grazers of bacteria and also point to their potential importance as grazers of phytoplankton. However, there are also results indicating that flagellates are not the sole grazers of the bacterial community (Landry et al. 1984, Sherr et al. 1984, 1986b).

In our calculations we have assumed all carbon to be autogenous. In a shallow sea area like the Gulf of Finland with long a coastal line and a number of rivers there is a possibility that a part of e. $\mathrm{g}$. the bacteria originates from terrestrial run-off. However, the study of Väätänen (1980b) suggests that our study area is relatively free of terrestrial influence.

The bacterial carbon requirement and direct flagellate grazing on phytoplankton make up nearly $35 \%$ of the net primary production. If sedimentation accounts for about $40 \%$ of net primary production (Kuparinen et al. 1984), only about 25 to $30 \%$ can be directly consumed by large heterotrophs. This emphasizes the importance of bacteria and heterotrophic flagellates in the pelagial ecosystem of the Tvärminne area, in contrast to the observation made from oligotrophic oceans (Landry et al. 1984, Joint \& Williams 1985).

This study has concentrated on the relationships among the smallest organisms in the pelagial ecosystem - phytoplankters, bacteria, flagellates - and on the effect of hydrographic conditions on their dynamics. Our material, although fairly extensive, shows the limitations of monitoring data of this kind. It is hard to explain all the observations, and to distinguish between cause and effect. There is also the possibility that a third, unknown parameter is controlling the dynamics of any 2 parameters studied and invalidating conclusions made about their interactions. We hope, however, that a monitoring study of this kind can provide some new information about the function of pelagial ecosystems, though still needing to be supplemented with careful experimental work.

Acknowledgements. This study was carried out at Tvärminne Zoological Station as a contribution to the PELAG project. Financial support from the Emil Aaltonen, the Walter and Andrée de Nottbeck, and the Maj and Tor Nessling Foundations is gratefully acknowledged. English was checked by Mrs Anna Damström, M. A.

\section{LITERATURE CITED}

Andersen, T., Fenchel, T. (1985). Bacterivory by microheterotrophic flagellates in seawater samples. Limnol. Oceanogr. 30: $198-202$

Andersen, P., Sørensen, H. M. (1986). Population dynamics and trophic coupling in pelagic microorganisms in eutrophic coastal waters. Mar. Ecol. Prog. Ser. 33: 99-109
Azam, F., Ammerman, J. W (1984). Mechanisms of organic matter utilization by marine bacterioplankton. In: HolmHansen, O., Bolis, L., Gilles, R. (eds.) Marine phytoplankton and productivity. Springer-Verlag, Berlin, Heidelberg, New York, Tokyo, p. 45-54

Azam, F., Fenchel, T., Field, J. G., Meyer-Reil, L.-A., Thingstad, F. (1983). The ecological role of water-column microbes in the sea. Mar Ecol. Prog. Ser 10: 257-263

Bell, R. T (1986). Thymidine incorporation as a measure of bacterial production in lakes. Acta Univ. Ups. Nova Acta R. Soc. Scient. upsal VC 43: 1-31

Bird, D. F., Kalff, J. (1986). Bacterial grazing by planktonic lake algae. Science 231: 493-495

Bird, D. F., Kalff, J. (1987). Algal phagotrophy: regulating factors and importance relative to photosynthesis in Dinobryon (Chrysophyceae). Limnol. Oceanogr. 32: $277-284$

Björnsen, P. K. (1986). Bacterioplankton growth yield in continuous seawater cultures. Mar. Ecol. Prog. Ser. 30: 191-196

Borsheim, K. Y., Bratbak, G. (1987). Cell volume to cell carbon conversion factors for a bacterivorous Monas sp. enriched from seawater. Mar. Ecol. Prog. Ser. 36: 171-175

Estep, K. W., Davis, P. G., Keller, M. D., Sieburth, J. McN. (1986). How important are oceanic algal nanoflagellates in bacterivory? Limnol. Oceanogr. 31: 646-650

Fenchel, T (1982). Ecology of heterotrophic microflagellates. IV. Quantitative occurrence and importance as bacterial consumers. Mar. Ecol. Prog. Ser. 9: 35-42

Fenchel, $\mathrm{T}$. (1986). The ecology of heterotrophic microflagellates. In: Marshall, K. C. (ed.) Advances in microb. ecology. Vol. 9. Plenum Publ. Corp., New York, p. 57-97

Forsskăhl, M., Sundberg, A. (1981). Abundance, biomass, species composition of phyto- and zooplankton and their interrelations at the entrance to the Gulf of Finland in 1979. Meri 9: 43-55

Fuhrman, J. A., Azam, F. (1980). Bacterioplankton secondary production estimates for coastal waters of British Columbia, Antarctica and California. Appl. environ. Microbiol. 39: 1085-1095

Fuhrman, J. A., Azam, F. (1982). Thymidine incorporation as a measure of heterotrophic bacterioplankton production in marine surface waters: evaluation and field results. Mar. Biol. 66: 109-120

Gast, V (1985). Bacteria as a food source for microzooplankton in the Schlei Fjord and Baltic Sea with special reference to ciliates. Mar. Ecol. Prog. Ser. 22: 107-120

Goldman, J. C., Caron, D. A. (1985). Experimental studies on an omnivorous microflagellate: implications for grazing and nutrient generation in the marine microbial food chain. Deep Sea Res. 32: 899-915

Haas, L. W. (1982). Improved epifluorescence microscopy for observing planktonic microorganisms. Annls Inst. océanogr., Paris 58 (Suppl.): 55-60

Haas, L. W., Webb, K. L. (1979). Nutritional mode of several non-pigmented microflagellates from the New York River Estuary, Virginia. J. exp. mar. Biol. Ecol. 39: 125-134

Hällfors, G., Leskinen, E., Niemi, $\AA$. (1983). Hydrography, chlorophyll $a$ and nutrients at Tvärminne Storfjärd, Gulf of Finland, in 1979/1980. W. \& A. de Nottbeck Found. sci. Rep. 4: 1-19

Hobbie, J. E., Crawford, C. C. (1969). Respiration corrections for bacterial uptake of dissolved organic compounds in natural waters. Limnol. Oceanogr. 14: 528-532

Huttunen, M., Kuparinen, J. (1986). Species succession and productivity of ultraphytoplankton in the pelagic off Tvärminne, SW coast of Finland. Ophelia (Suppl.) 4: 73-83 
Joint, I. R., Williams, R. (1985). Demands of the herbivore community on phytoplankton production in the Celtic Sea in August. Mar. Biol. 87: 297-306

Kuosa, H., Marcussen, B. (1988). Grazing of bacteria and phytoplankton by heterotrophic nanoflagellates in a Baltic Sea sample. In: Jones, R. I., IImavirta, V. (eds.) Flagellates in freshwater ecosystems. Hydrobiologia 161: 211-216

Kuparinen, J. (1984). Annual and seasonal fluctuation of primary productivity and overall respiration in a pelagic plankton community off Tvärminne, SW coast of Finland. Ophelia (Suppl.) 3: 111-122

Kuparinen, J. (1987). Production and respiration of overall plankton and ultraplankton communities at the entrance to the Gulf of Finland in the Baltic Sea. Mar. Biol. 591-607

Kuparinen, J., Leppänen, J.-M., Sarvala, J., Sundberg, A., Virtanen, A. (1984). Production and utilization of organic matter in a Baltic ecosystem off Tvärminne, southwest coast of Finland. Rapp. P.-v. Réun. Cons. int Explor. Mer 183: $180-192$

Lampert, W. (1978). Release of dissolved organic carbon by grazing zooplankton. Limnol. Oceanogr. 23: 831-834

Landry, M. R., Haas, L. W., Fagerness, V. L. (1984). Dynamics of microbial plankton communities: experiments in Kanohoe Bay, Hawaii. Mar. Ecol. Prog. Ser. 16: 127-133

Larsson, U., Hagström, $\AA$ (1979). Phytoplankton exudate release as an energy source for the growth of pelagic bacteria. Mar. Biol. 52: 199-206

Larsson, U., Hagström, $\AA$. (1982). Fractionated phytoplankton. primary production, exudate release and bacterial production in a Baltic eutrophication gradient. Mar. Biol. 67: 57-70

Lignell, R., Kuosa, H. (1988). Sources of error in algal exudation measurements. Arch. Hydrobiol. Beih. Ergeb. Limnol. 31. 97-104

Linley, E. A. S., Newell, R. C., Lucas, M. I. (1983). Quantitative relationships between phytoplankton, bacteria and heterotrophic microflagellates in shelf waters. Mar Ecol. Prog. Ser. 12: 77-89

Marchant, H. J. (1985). Choanoflagellates in the Antarctic marine food chain. In: Siegfried, W. R., Condy, P. R., Laws, R. M. (eds.) Antarctic nutrient cycles and food webs. Springer-Verlag, Berlin, p. 271-276

Meyer-Reil, L. -A. (1977). Bacterial growth rates and biomass production. In: Rheinheimer, G. (ed.) Microbial ecology of a brackish water enrironment. Springer-Verlag, Berlin, p. 223-236

Niemi, M., Kuparinen, J., Uusi-Rauva, A., Korhonen, K (1983). Preparation of ${ }^{14} \mathrm{C}$-labelled algal samples for liquid scintillation counting. Hydrobiologia 106: 149-156

Niemi, A. (1973). Ecology of phytoplankton in the Tvärminne area, SW coast of Finland, I. Dynamics of hydrography. nutrients, chlorophyll-a and phytoplankton. Acta bot. fenn. 100: $1-68$

Niemi, $\AA$. (1975). Ecology of phytoplankton in the Tvärminne area, SW coast of Finland. II. Primary production and environmental conditions in the archipelago zone and the sea zone. Acta bot. fenn. 105: 1-73

Pollard, P. C., Moriarty, D. J. W. (1984). Validity of the tritiated thymidine method for estimating bacterial growth rates measurement of isotope dilution during DNA synthesis Appl. environ. Microbiol. 48: 1076-1083
Rassoulzadegan, F., Sheldon, R. W. (1986). Predator-prey interactions of nanozooplankton and bacteria in an oligotrophic marine environment. Limnol. Oceanogr. 31: 1010-1021

Rheinheimer, G. (1984). The role of small heterotrophs (bacteria and protozoa) in a shelf exosystem. Rapp. P.-v. Réun. Cons. int Explor. Mer 183: 144-151

Riemann, B., Bjørnsen, P. K., Newell, S., Fallon, R. (1987). Calculation of cell production of coastal marine bacteria based on measured incorporation of $\left[{ }^{3} \mathrm{H}\right]$ thymidine. Limnol. Oceanogr. 32: 471-476

Rivier, A., Brownlee, D. C., Sheldon, R. W., Rassoulzadegan, F (1985). Growth of microzooplankton: a comparative study of bactivorous zooflagellates and ciliates. Mar Microb Food Webs 1. 51-60

Sherr, E. B., Sherr, B. F. (1987). High rates of consumption of bacteria by pelagic ciliates. Nature, Lond. 325: 710-711

Sherr, B. F., Sherr, E. B., Andrew, T. L., Fallon, R. D., Newell, S. Y (1986a). Trophic interactions between heterotrophic protozoa and bacterioplankton in estuarine water analyzed with selective metabolic inhibitors. Mar. Ecol. Prog. Ser. 32: 169-179

Sherr, B. F., Sherr, E. B., Newell, S. Y. (1984). Abundance and productivity of heterotrophic nanoplankton in Georgia coastal waters. J. Plankton Res. 6: 195-202

Sherr, E. B., Sherr, B. F., Paffenhöfer, G.-A. (1986b). Phagotrophic protozoa as food for metazoans: a missing trophic link in marine pelagic food webs? Mar. Microb. Food Webs 1: $61-80$

Sissenwine, M. P., Cohen, E. B., Grosslein, M. D. (1984). Structure of the Georges Bank ecosystem. Rapp. P.-v. Réun. Cons. int. Explor. Mer 183: 243-254

Smetacek, V., von Bodungen, B., Knoppers, B., Peinert, R. Pollehne, F., Stegmann, P., Zeitzschel, B. (1984). Seasonal stages characterizing the annual cycle of an inshore pelagic system. Rapp. P.-v. Réun. Cons. int. Explor. Mer 183: $126-135$

Smith, R. E. H. Harrison, W G., Irwin, B., Platt, T. (1986) Metabolism and carbon exchange in microplankton of the Grand Banks (Newfoundland). Mar. Ecol. Prog. Ser. 34: $171-183$

Steemann Nielsen, E. (1952). The use of radioactive carbon $\left(\mathrm{C}^{14}\right)$ for measuring organic production in the sea. J. Cons perm. int. Explor. Mer 18: 117-140

Suttle, C. A., Chan, A. M., Taylor, W. D., Harrison, P. J. (1986) Grazing of planktonic diatoms by microflagellates. J. Planton Res. 8: 393-398

Väätänen, P. (1980a). Effects of environmental factors on microbial populations in brackish waters off the southern coast of Finland. Appl. environ. Microbiol. 40: 48-54

Väätänen, P. (1980b). Microbiological parameters for differentiating between coastal and open waters in the Northern Baltic proper and the Gulf of Finland. J. appl. Bact. 49 $455-462$

Virtanen, A. (1985). Bacterial numbers, biomass, activity and production at a site in the Tvarminne area of the Gulf of Finland. Aqua fenn. 15: 143-160

Williams, J. J. leB. (1981). Incorporation of the microheterotrophic processes into the classical paradigm of the planktonic food web. Kieler Meeresforsch., Sonderh. 5: 1-28

Manuscript first received: February 23, 1988

Revised version accepted: January 18, 1989 